\title{
Revival of "Dollar Diplomacy" As United States Foreign Economic Policy in 2017: Tradeoffs Exchanged to Maintain Trade and Restore Peace Along the Tottering Western Pacific Rim
}

\author{
David A. Jones ${ }^{1}$ \\ Professor of Foreign Policy, International Law, International Management, \\ Institute of The Americas and Europe, Institute of International Relations, \\ and Faculty of Management, University of Warsaw
}

\begin{abstract}
Background, Objectives and Goals: From their auspicious meeting at the "Southern" White House, Mar-a-Lago, West Palm Beach, Florida on 5-6 April 2017, U.S. President Donald J. Trump and China's President Xi Jinping seem to have struck up a friendship accord intended to maintain, hopefully augment, Western trade with China and in the process diffuse burgeoning tensions along the Western Pacific rim caused by aggressive rhetoric and belligerent behavior of Kim Jong-Un, leader of the "Democratic" People's Republic of Korea [North Korea]. In the process, the United States appears to be recasting its foreign economic policy as a return to "Dollar Diplomacy," the hallmark of American foreign policy during the William Howard Taft presidency (1909 - 1913), mostly out of favour since then until the present moment. An objective of this paper is to clarify and articulate characteristics of "Principled Dollar Diplomacy" in the $21^{\text {st }}$ century compared with its $2^{\text {th }}$ century counterpart, to identify what will be its objectives and goals, then to assess the viability and sustainability of the same globally but especially along Asia's Western Pacific rim, connecting to South and West Asia then Europe along the ancient "Silk Road" of Eurasia as an integral part of President Trump's "Principled Realism" in foreign policy. Methods: Literature reviewed include historiographical documents reflecting both the current state of, and recent changes to, United States foreign economic policy globally, termed "Principled Realism" by President Trump as it interfaces foreign economic policy with foreign security policy, focusing particularly on what appears to be a tottering Western Pacific rim of mainland Asia, fragmented by hostile rhetoric, nuclear threats, China's unilateral South China Sea domination. Government reports by individual countries and trading partners plus journalistic accounts, together with diplomatic interviews have been reviewed. Attention is directed to changes in trade volume involving trading partners generally, together with trade values of both imports and exports across the first six months of the Donald Trump administration compared to similar periods in administrations of former American presidents from Theodore Roosevelt to Barrack Obama. Presidential rhetoric will be analysed as communicated to three categories of recipients: foreign heads of state or heads of government, United States business leaders, the global general public. Some historical records are included, comparing Chinese maritime belligerence along the Western Pacific rim with similar activities engaged in by Imperial Germany during World War I then by Nazi Germany during World War II, each with disastrous consequences. Expected Results: Ever since the Florida summit meeting between Presidents Trump and Xi, an economic dialogue appears to have emerged that
\end{abstract}

\footnotetext{
1 Professor dr hab. DAVID A. JONES, Ph.D., Sc.D., D.Jur. is professor of international law, international management, international relations at the University of Warsaw, Poland, where he serves on the faculties of the Institute of The Americas and Europe, the Institute of International Relations, and the Faculty of Management. He has been a senior graduate lecturer at Norwich University, the Military Academy of the State of Vermont, since 2006.
} 
has expanded into diplomatic discussions involving the DPRK, Association of South East Nations (ASEAN) partners trading with both China and the United States, India, Japan, South Korea. Predicated upon President Trump's self-assessment of his first 100 days in office, together with legitimate expectations of other nations, it should be possible to gauge the direction of "Dollar Diplomacy" across the first and second 100 days to predict the Strengths and Weaknesses of early changes in United States foreign economic policies over the first six months of the Trump Administration. Positive or negative results should be apparent in trade regimes, trade value, trade volume, as well as changes in rhetoric along the Western Pacific rim, and intensity of involvement if the state parties themselves. Stated succinctly, this is China's chance to stand out and become a leader, potentially the leader, in Asia, and to work hand in hand with the United States and the Western Alliance to maintain continuity of "Pax Americana" for another 70 years or longer, an enduring peace from which, arguably, China has benefitted more than most countries, and stands to benefit much more across eight more decades of the $21^{\text {st }}$ century. Amongst other factors, an expectation is to witness the United States and other Western Allies join with China in funding its "One Belt, One Road" or "OBOR" across Eurasia, because by partnering a rapprochement with DPRK, China and the United States should grow closer, greater and fairer trade should emerge between these two nations, that burgeoning friendship should draw in Japan and other huge trading partners of both. Possible as a successor to the ill-fated Trans-Pacific Partnership will be a sustainable "Pax Pacifica" reflecting core values of the West alongside China's stated commitment to decreasing poverty in developing countries, providing an enormous opportunity for the Trump and Xi Administrations to cooperate harmoniously. In addition to the Pacific rim as a region, the DPRK could benefit from Sino-American investment inside of its borders, particularly if China and the West could construct international joint ventures (IJVs) in the region with each functioning as a check and a balance on the other.

Keywords. Asia, China, "Pax Pacifica”, "Principled Dollar Diplomacy”, IJVs, "Spillover”.

\section{INTRODUCTION}

Asia is basking in diverse controversy as the "Democratic" People's Republic of Korea (DPRK, North Korea) persists in displaying its military credibility notwithstanding United Nations (UN) sanctions, and as the People's Republic of China (PRC, China) continues to expand and enlarge its foothold over the East and South China Seas, testing the Alliance (Varandani, 2017). Collectively and each individually, these events challenge the Pax Pacifica and invite intervention from the United States, United Kingdom, plus rising Asian economic powers such as India and Japan together with Eurasian powers in decline such as the Russian Federation. States must select their partners prudently from an array that most noticeably includes China and the United States. Academic and journalistic pundits predict that China and the United States are heading to war (Allison, 2017, 2015; Farley, 2014; Gompert, Cevallos \& Garafola, 2016). Definitely they are not, neither desires war against the other, each has too much to lose, as others have pointed out also (Buruma, 2017; Etzione, 2017). This is the point exactly and entirely: the West must make China and China's allies have more to lose than to gain through warfare. That is the objective of "Dollar Diplomacy" in revival, not through the fist but through the purse, as China transitions from an exporter to an importer. We do not live in and we are not heading toward the "post-American world" that Zakaria forecasted in 2009, nor is the West falling just because Asia is rising, as Rachman contends in 2017. As China changes from an exporting to an importing nation, fortunes will change as Guo and Gough have predicted (2016). Fortunes will change differently from predictions, however: China's "bubble" will burst as it becomes forced to buy from rather than to sell to the world, and the "China Dream" of displacing the United States as global hegemon, imagined by Liu (2010), ${ }^{2}$ will fade into

\footnotetext{
2 The book China Dream is not available in English. For a review of this book, see Saunders, Phillip C. 2010. "Will China's Dream Turn Into America's Nightmare?" China Brief, Vol. 10, No. 7. Washington: Jamestown Foundation. http://www.jamestown.org/single/?no cache=1\&tx ttnews\%5Btt news\%5D=36217\&tx ttnews $\% 5 B b a c k P i d \% 5 D$
} 
oblivion. The Western Alliance can help that "bubble" to burst, then help the Chinese people to join with the West to enjoy a higher quality of life for themselves and their posterity, by readopting a programme of "Dollar Diplomacy" if not worldwide, which would be ideal, then at least in every corner of the world where China is advancing its "New Silk Road" or "New Silk Route," together forming "One Belt, One Road" or "OBOR." Much of that currently is in South Asia, West Asia, and East Europe, with an aim of expanding across Eurasia then Europe.

\section{BACKGROUND}

"Dollar Diplomacy," as implied by this nomenclature itself, involves the expenditure of dollars in diplomatic endeavours (Trani, 2002). Although "Dollar Diplomacy" originated as a form of United States foreign economic policy during Theodore Roosevelt's administration (19011909), it is widely associated with the presidency of William Howard Taft (1909-1913), and President Taft used the words "Dollar Diplomacy" in his last message to Congress to characterise his foreign policy (Taft, 1912). Some presidential successors including mainly Herbert C. Hoover (1929-1933) denigrated "Dollar Diplomacy." It had its value, however, in the way Taft and his secretary of state, Philander Chase Knox, used it: to encourage private sector United States companies to invest in tottering regions of the world, most notably East Asia and Latin America, in an effort to stabilise governments, increase American influence and expand markets for American products, reduce to a minimum the need for military intervention, although that option remained (Nearing \& Freeman, 1925, 266). President Taft summarised "Dollar Diplomacy" as "substituting dollars for bullets" in his fourth address to the Congress on 03 December 1912, 89 years to the day after enunciation of the Monroe Doctrine, with Taft declaring his policy to be:

one that appeals alike to idealistic humanitarian sentiments, to the dictates of sound policy and strategy, and to legitimate commercial aims. It is an effort frankly directed to the increase of American trade upon the axiomatic principle that the government of the United States shall extend all proper support to every legitimate and beneficial American enterprise abroad (Taft, 1912).

Clearly, in "Dollar Diplomacy" the Taft administration envisioned enlargement of an American presence globally together with expanded sales abroad of products made in America, each boosting an American image worldwide as envisioned by its architect for East Asia, assistant secretary of state Willard Dickerman Straight (Kahn, 1974). Both are or should be core objectives of United States foreign economic policy in the $21^{\text {st }}$ century as well. They seem to interface well with articulated foreign economic policies of President Donald J. Trump, labeled by Trump himself as "Principle Realism" recently (Fairouz, 2017).

What has been termed "Dollar Diplomacy in Reverse" is evidenced in some aspects of $21^{\text {st }}$ century Chinese foreign economic policy since China's "Liberation" in 1949 (Jones \& Liu, 2013), because China has invested its own United States Dollar reserves to build infrastructure in many parts of the world, Africa particularly. Most of the Chinese foreign investment is derived from China's sovereign wealth, however, meaning from the people's assets, much of that wealth coming from State Owned Enterprises (SOEs) that in turn are thinly-disguised vehicles crafted to launder state funds by corrupt current or former public officials. Many SOEs are controlled by "red princelings," scions of early communist leaders or their collaborators. This leads to faction rivalries, changing factions, cross-allegations of corruption such as against Guo

=7\&cHash=19fc1b4da3. Kissinger attributes "marathon contest" and "duel of the century" to Saunders, 10. See Kissinger, Henry A. 2012. On China. New York: Penguin Books, 565, n.8. 
Mingui (alias "Miles Kwok") who in turn is hurling corruption allegations against President Xi Jinping's anti-corruption "tsar," Wang Qishan, prompting the latter to request a "red alert" against Guo from Interpol, currently headed by former Chinese deputy national security head Meng Hongwei (Bao, 2017). It is convenient for China to have its operative in charge of Interpol, much as Nazi Führer Adolph Hitler found it convenient to install his henchman Reinhard Heydrich as president of the National Criminal Police Commission (NCPC), original name of Interpol, 1940 to 1942. It is evident that "China's robber barons take collusion to a whole new level" (X. Wang, 2017), as reported by the South China Morning Post, controlled by Alibaba, itself an entity with obscure ownership (Ford, 2014), itself fraught with corruption in the form of counterfeit products leading it to with its subsidiary, Taobao, to be targeted as a "notorious marketplace" with "widespread availability of counterfeit and pirated goods" by the United States Trade Representative between 2008 and 2012 (Yan, 2014).

"Dollar Diplomacy" in the sense it was developed by Taft and Knox (with Straight for Asia) avoids sovereign wealth to a large extent, encouraging private sector investment from wealthy individuals, affluent corporations, searching for diversified portfolios and growth of wealth. Thus, it was intended not to become a drain upon parent country sovereign wealth, but instead an opportunity for private sector Foreign Direct Investment (FDI). In addition to East Asia, Cuba was recipient of significant "Dollar Diplomacy" investment in the Taft administration, with the United States receiving sharp criticism on account of the rapid decline in family ownership of farmland replaced by large corporate land holdings that left longtime Cuban landowners destitute (Perez, 1989, 137; Beals, 1933, 193). Some authors have reached the conclusion, as one articulated:

The state of affairs on the island changed in a way contrary to what [P]resident Taft and Secretary Knox intended. Instead of bringing prosperity, stability and contributing to the advent of a strong middle class, dollar diplomacy was responsible for a shift in the socio-economic structure of Cuba dominated by increasing poverty, dependency, disrupted families, and social conflict (Timoneda, 2008, 276).

So "Dollar Diplomacy" revived in the $21^{\text {st }}$ century must be more "principled" than it was in the past. Arguably, China's OBOR poses the same risk, but that risk should be reduced by competition in the form of Western including American "Dollar Diplomacy" alongside the Chinese "Silk Road" initiative. Stated differently, if China and other countries are bent on pursuing "Dollar Diplomacy" then the United States and the Western Alliance should do the same, to keep the playing field as level as possible. Risk will continue that "Dollar Diplomacy" recipient nations in any form will become export economies, at least up to the time when they reach full development, because of the proclivity of investors with any mindset to repatriate investment profits sooner than in the best interests of the recipient state's economy. Reaching the recipient population and raising their quality of life was addressed as a "core value" of China by Hong Xiaonan, dean at the Dalian University of Technology, at the $4^{\text {th }}$ National Development Strategy Forum in China, Russia and Mid-Eastern European Countries held at Vistula University, Warsaw, Poland on 04 June 2017, to the day the $75^{\text {th }}$ anniversary of the battle of Midway that secured China's freedom (Farley, 2017). At the same conference on the theme of "Future Trend of International Structure Change and Recombination Between China and Poland," co-sponsored by Vistula University and the Psychology Institution of Social Science of China, by invitation this author gave a lecture comparing China's professed "core values" to United States President Lyndon Baines Johnson's effort to deliver Federal funding directly to black and female citizens, part of America's "War on Poverty," to minimise scarfing by state and local government officials (Jones, 2016), at risk in China's own OBOR and in "Dollar Diplomacy" generally. 
China casts itself in the peculiar cloak of "Advanced Economy" or AE by daylight, then of an "Emerging Market" at night, although it is difficult to witness China as being both at once.

Figure 1.

These G-20 members are set for the largest boost in per capita GDP rank

\begin{tabular}{|c|c|c|c|c|c|}
\hline & $\begin{array}{l}\text { 1992-2022 } \\
\text { Rank } \\
\text { Change }\end{array}$ & $\begin{array}{l}2022 \\
\text { Rank }\end{array}$ & $\begin{array}{l}2022 \text { PPP. } \\
\text { Adjusted Per } \\
\text { Capita GDP* }\end{array}$ & $\begin{array}{l}1992 \\
\text { Rank }\end{array}$ & $\begin{array}{l}1992 \text { PPP. } \\
\text { Adjusted Per } \\
\text { Capita GDP* }\end{array}$ \\
\hline China & $69 \Lambda$ & 64 & $\$ 23,960$ & 133 & $\mid \$ 1,261$ \\
\hline India & $27 \Delta$ & 107 & | \$10,893 & 134 & $\mid \$ 1,261$ \\
\hline South Korea & $19 \Delta$ & 29 & $\$ 49,772$ & 48 & | $\$ 9,123$ \\
\hline Indonesia & $13 \Delta$ & 84 & \16,887 & 97 & $\mid \$ 3,418$ \\
\hline Australia & $9 \Delta$ & 16 & $\$ 60,534$ & 25 & $\$ 19,670$ \\
\hline
\end{tabular}

SOURCE: Tartar, Andre, and Wei Lu. 2017. “China's Rags-to-Riches Transformation Isn't Over Yet," Bloomberg. 25 Jun. https://www.bloomberg.com/amp/news/articles/2017-06-25/there-sno-end-in-sight-for-china-s-rise-up-the-gdp-rankings, from International Monetary Fund data. Note: PPP values are in current international USD terms.

It stands to gain Purchasing Power Parity (PPP) markedly in the next five year period (Tartar \& $\mathrm{Lu}, 2017)$, as Figure 1 below reflects, suggesting strongly that China is an AE masquerading as an EM, this charade unmasked by the huge FDI it is earmarking for its "Silk Road" initiative.

\section{ALTERNATIVES TO “DOLLAR DIPLOMACY”}

Once President Taft was defeated in his bid for re-election in 1912, (Thomas) Woodrow Wilson as his successor reversed much "Dollar Diplomacy" and redirected America's attention toward the defence of Europe against Imperial Germany, to be followed a generation afterwards by the defence of Europe against NAZI Germany then the Soviet Union (Roberts, 1994; Roberts, 1997). That "Atlanticism" turned into an "Anglophile internationalist tradition" (Roberts, 2005) before coming into question on account of "fraying" European-American ties witnessed at least as far back as 2006 (Wither, 2006) but exacerbated during and following the Russian Federation's foray into Ukraine in 2014 and thereafter. Stronger by far than any other element of "Atlanticism" is the "special relationship" between the United Kingdom and United States. More than any other single factor, and more than most other factors collectively, it is this Alliance that will enable the United States and the West to "escape Thucydides's Trap" as Allison framed this issue in 2015 and 2017, if only because the "trap" articulated by Thucydides was the absence of an alliance rather than its existence. No alternative foreign policy including "Dollar Diplomacy" (that does not have to be an alternative policy) will effectively replace the Anglo-American Alliance, most evident currently in the North Atlantic Treaty Organisation (NATO) in Europe and the Middle East. An example of "Dollar Diplomacy" working in concert with NATO is the European Recovery Program (ERO), more commonly known as the Marshall Plan of 1948, where the infusion of USD 12 Billion plus another USD 1.5 Billion in loans was designed to reverse a European trade deficit with the United States, ultimately to make European nations strong trading partners with the United States. Critics of the Marshall Plan have emerged decade after decade (Hazlitt, 1947; Greenspan, 2008), with Greenspan arguing that regulatory reductions contributed as much as the infusion of money to European recovery. "Dollar Diplomacy" should be added to "Atlanticism" that must be maintained at full strength, potentially complemented by, a parallel "Pacificism" in the form of 
an increasingly stronger American-Japanese Alliance in Asia, coupled by an un-eroding Australian-New Zealand-British-American Alliance.

\section{DOLLAR HEGEMONY}

Rumours abound concerning what nations will join in China's initiative to invest substantial capital into infrastructure across Eurasia and elsewhere, and under what conditions. According to China, the United States is considering becoming China's partner on OBOR (Han, 2017), India has signaled conditions for its support (Pant, 2017), Japan has conditioned its support in China agreeing to greater OBOR transparency (Pollmann, 2017), free passage of Japanese shipping (including shipping of arms) across the South China Sea region (Kelly \& Kubo, 2017) plus China agreeing to Japan selling arms to Association of Southeast Asia Nations (ASEAN) bloc then transporting them across the South China Sea (Yamaguchi, 2017). An unspoken "condition" looms in the background: that is that the universe of Chinese development projects continue to be invested in dollars, to maintain "Dollar Hegemony" as former United States Congressman and Libertarian Party presidential candidate Ron Paul put it in 2006. Perhaps this is one reason why the Japanese head of the Asian Development Bank (ADP), Takehiko Nakao, conceded recently at the ADP's 50 th anniversary meeting that ADP and the Asian Infrastructure Investment Bank (AIIB) formed and led by China can partner (Flores, 2017). Care must be taken, however, that the funding extended to recipient nations is more than "paper" currency such as China continues to print with decreasing real value to back it up. Is China "moderating" its economic weaknesses, as B. Wang (2017) contends predicated upon data reflected below in Figure 2, or is the same data adumbrative of financial instability. If the latter, then that instability can spillover into emerging markets all along China's "Silk Road" and elsewhere.

Figure 2.

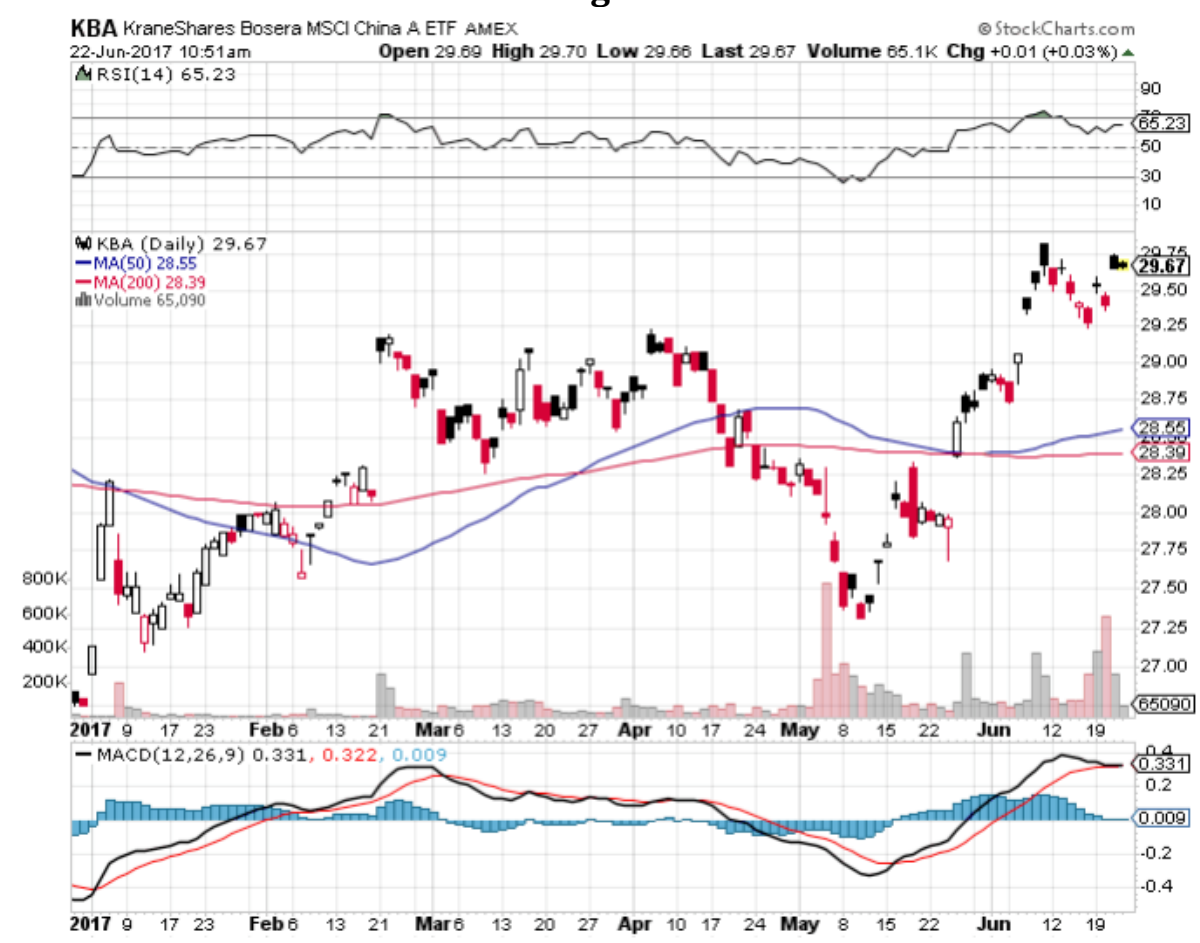

SOURCE: Wang, Brian. 2017. “China is moderating economic weaknesses and may become reliable global engine in 5-15 years," NextBigFuture. 25 Jun.

https://www.nextbigfuture.com/2017/06/china-is-moderating-economic-weaknesses-andmay-become-reliable-global-engine-in-5-15-years.html 


\section{PRINCIPLED “DOLLAR DIPLOMACY.”}

Amongst many internal Strengths and Weaknesses, external Opportunities and Threats of FDI or loans to Emerging Markets (Ems), one threat looms above the others: "neighbourhood spillover" that can occur when countries that are close to each other geographically or aligned economically, according to the International Monetary Fund (IMF), particularly where "China is the second-largest exporter of capital in the world, after the United States, and China's central bank is the largest purchaser of U.S. financial assets" (Spillover Report, 2014, 72). Accordingly, that report issued the following admonishment:

Over the past decade, there has been a dramatic increase in the degree of regional integration, especially in Asia. Intraregional trade represents an increasingly larger share of global trade. Cross-border financing flows among EMs in certain regions have expanded progressively since the early 2000s. As regional linkages strengthen, the exposure of countries to shocks originating in the biggest economies in the region rises. This underlines the significance of localized spillover effects from a deceleration in large Ems (Spillover Report, 2014, 73 [citations omitted]).

An unspoken implication of "neighbourhood spillover" is the effect an important change or set of changes within China's economy would exert upon nations that are or will become recipients of Chinese "Dollar Diplomacy" along its "New Silk Road. To a lesser extent, perhaps, is the effect an important change or set of changes within the economy of one or more such recipient nations would exert upon the rest. It is for this reason, or these interfacing reasons, that the United States should partner with China on the latter's OBOR initiative, as well as compete with China's own "Dollar Diplomacy" by encouraging an American "Principled Dollar Diplomacy."

To be "principled" FDI must be transparent as Japanese prime minister Shinzo Abe notes (Pollmann, 2017), but more is required, including especially the following seven points:

1. "Dollar Diplomacy" must be subject to $21^{\text {st }}$ century global auditing standards that require transparent accounting practices.

2. "Dollar Diplomacy" must involve funding that is balanced across geographic sectors, to minimise "neighbourhood spillover" effects.

3. "Dollar Diplomacy" must be functionally insured, meaning protected against willful losses such as "firesale" sell offs, expropriation, or "round-tripping" (where the done of FDI becomes the donor in reverse direction) by recipient nations or individuals in general to protect against inappropriate collaboration.

4. "Dollar Diplomacy" has to be goal-driven, tied specifically to clearly-articulated aims and objectives, so that recipients whether they be nations or private sector companies will be fully cognizant of the legitimate expectations of foreign direct investors.

5. "Dollar Diplomacy" requires periodic, impartial assessments to determine the impact of the same upon the population of recipient nations, to be conducted by respected international organisations, to ensure that what was intended to benefit recipients does not turn out to harm them, or to help some at the expense of others.

6. "Dollar Diplomacy" is likely to and should foster International Joint Ventures (IJVs), but these must be transparent, disclosed to the international community, to preclude peaceful intentions from becoming catalysts of belligerence.

7. "Dollar Diplomacy" must not become a mechanism for tax avoidance in either the nation from which the funding originates or the nation where funding is received, requiring full disclosure at time of funding of legitimate expectations for both the repatriation of the invested corpus and the repatriation of returns on investment. 


\section{CONCLUSION}

"Dollar Diplomacy" in United States foreign economic policy has enjoyed mixed outcomes, with the positive far exceeding the negative. At an early stage in the Donald J. Trump presidency, some indications point to his inclination to revive "Dollar Diplomacy" and this would be good. Several features of China's "One Belt, One Road" initiative across Eurasia are adumbrative of its adoption of "Dollar Diplomacy," and this provides the United States and the West with several options: join China, compete with China, do both, with the latter being the best option. American, British, and Japanese money particularly should be poured into some of China's "Silk Road" programmes to enable the West to gain access to details of Chinese ventures. In tandem, the same Western players should compete with China by way of their own "Dollar Diplomacy," thus securing recipient nations against the deleterious effects that will follow bursting of the "bubble" China's "Silk Road" is creating. All FDI should be "principled" meaning transparently audited, balanced across geographic regions, safeguarded from inappropriate collaboration.

\section{LIST OF SOURCES}

Allison, Graham. 2017. Destined for War: Can America and China Escape Thucydides's Trap? Boston: Houghton Mifflin Harcourt.

Allison, Graham. 2015. "The Thucydides Trap: Are the U.S. and China Headed for War?” The Atlantic. 24 Sep. https://www.theatlantic.com/international/archive/2015/09/united-states-china-war-thucydides$\operatorname{trap} / 406756 /$

Bao, Pu. 2017. "The Other Side of 'the Biggest Political Story in China'," Stratfor. 16 Jun. https://www.stratfor.com/article/other-side-biggest-political-story-china

Beals, Carlton. 1933. The Crime of Cuba. Philadelphia: J.B. Lippincott Co.

Behrman, Greg. 2008. The Most Noble Adventure: The Marshall Plan and How America Helped Rebuild Europe. New York: Free Press.

Brown, Matthew. 2017. "Singapore offers to help bankroll China's global ambitions," The Washington Post. 12 Jun. https://www.washingtonpost.com/world/asia_pacific/singapore-offers-to-help-bankroll-chinas-globalambitions/2017/06/12/ace022e2-4f4e-11e7-b74e-0d2785d3083d_story.html?utm_term=.32b0f38f7055

Buruma, Ian. 2017. “Are China and the United States Headed for War?” The New Yorker. 19 Jun. http://www.newyorker.com/magazine/2017/06/19/are-china-and-the-united-states-headed-for-war

Etzioni, Amitai. 2017. Avoiding War with China: Two Nations, One World. Charlottesville, VA: University of Virginia Press.

Fairouz, Mohammed. 2017. "Principled realism and an emerging Trump doctrine," The National. 22 May. http://www.thenational.ae/opinion/comment/principled-realism-and-an-emerging-trump-doctrine

Farley, Robert. 2014. “Asia's Greatest Fear: A U.S.-China War,” The National Interest. 09 Jun. http://nationalinterest.org/feature/asia-flames-us-china-war-10621

Farley, Robert. 2017. “Why USS Enterprise Is The Best U.S. Navy Ship Ever,” The National Interest. 23 Jun. http://nationalinterest.org/blog/the-buzz/why-uss-enterprise-the-best-us-navy-ship-ever-21293?page=2

Flores, Mikhail. 2017. “ADB chief: AIIB can be partner in filling Asia's infrastructure gap,” Nikkei Asian Review. 04 May. http://asia.nikkei.com/Spotlight/ADB-Annual-Meeting-2017/ADB-chief-AIIB-can-be-partner-in-filling-Asias-infrastructure-gap

Ford, John. 2014. "No One Who Bought Alibaba Stock Actually Owns Alibaba,” The Diplomat. 24 Sep. http://thediplomat.com/2014/09/no-one-who-bought-alibaba-stock-actually-owns-alibaba/

Gompert, David C., Astrid Cevallos, Cristina L. Garafola. 2016. War With China: Thinking Through the Unthinkable. Santa Monica, CA: Rand Corporation. file:///C:/Users/Windy/AppData/Local/Temp/RAND_RR1140.pdf

Greenspan, Alan. 2008. The Age of Turbulence: Adventures in a New World. New York: Penguin.

Guo, Owen, and Neil Gough. 2016. "As China Shifts from Exporter to Importer, Fortunes Change," The New York Times. 18 Oct. https://www.nytimes.com/2016/10/18/business/energy-environment/as-china-shifts-fromexporter-to-importer-fortunes-change.html 
Jones, D. A. (2017). Revival of “Dollar Diplomacy" As United States Foreign Economic Policy in 2017: Tradeoffs Exchanged to Maintain Trade and Restore Peace Along the Tottering Western Pacific Rim. Advances in Social Sciences Research Journal, 4(18) 86-96.

Han, Miao. 2017. "China Says Trump Open to Cooperating on Silk Road Projects," Bloomberg. 23 Jun.

https://www.bloomberg.com/news/articles/2017-06-23/china-says-u-s-is-willing-to-work-on-belt-and-roadinitiative

Hazlitt, Henry Stuart. 1947. Will Dollars Save the World? New York: D. Appleton - Century.

Jones, David A. 2016. “Microfinancing Abroad Along China's 'One Belt, One Road': Replicating the Wokai, Kiva and Other Experiments Worldwide and the American 'War On Poverty' Experience Internationally," Proceedings of the Ninth Annual Conference on Global Business, Economics, Finance and Banking (AP 16 Hong Kong), 1-10. 11-13 Aug. http://globalbizresearch.org/HongKong_Conference_2016_Aug/docs/doc/Global\%20Business,\%20Economics\% 20\&\%20Sustainability/HK631_Abstract.pdf

Jones, David A., and Hanzhen Liu. 2013. “From 'Renminbi Diplomacy' to 'Dollar Diplomacy' in Reverse: Changes in Chinese Foreign Economic Policy Since 1950," in Ma, Ming, ed. 2013.

Advances in Social and Behavioral Sciences. Singapore: Singapore Management and Sports Science Institute, Vol. 4, 68-72.

Kahn, Helen Dodson. 1974. "Willard D. Straight and the Great Game of Empire," in Merli, Frank J., and Theodore A. Wilson, eds. 1974. Makers of American Diplomacy: From Theodore Roosevelt to Henry Kissinger. New York: Charles Scribner's Sons.

Kelly, Tim, and Nobuhiro Kubo. 2017. "Arms show offers Japan venue to build military ties in Southeast Asia," Reuters Africa. 11 Jun. http://af.reuters.com/article/worldNews/idAFKBN19208K?sp=true

Ku, Julian. 2017. "Why the U.S. Can't Take Sides in South China Sea Sovereignty Disputes, Even Against China," Lawfare. 19 Jun. https://lawfareblog.com/why-us-cant-take-sides-south-china-sea-sovereignty-disputes-evenagainst-china

Liu, Mingfu. 2010. Zhongguo Meng: Hou Meiguo Shidai de DaGuo Siwei yu Zhanlüe Dingwei [China's Dream: Major Power Thinking and Strategic Posture in a Post-American Era]. Beijing: Zhongguo Youyi Chuban Gongsi [China Friendship Publishing Company]. The foreword and 3700 character table of contents are available at http://www.amazon.cn/mn/detailApp/ref=sr_1_1?_encoding=UTF8\&s=books\&qid=1270207625\&asin=B003554 $\mathrm{FE} 4 \& \mathrm{sr}=8-1$.

Locke, Alex. 2017. "Trump is breaking all of Obama's rules in Syria — and it seems to be working," Business Insider. 12 Jun. http://www.businessinsider.com/trump-obama-syria-iran-strike-red-line-2017-6?IR=T

McCleary, Kelly. 2017. “China sails into disputed waters, prompting protest by Japan," Cable News Network (CNN). 25 Jun. http://edition.cnn.com/2017/06/24/asia/china-japan-disputed-islands/index.html

Nearing, Scott, and Joseph Freeman. 1925. Dollar Diplomacy: A Study in American Imperialism. New York: B.W. Huebsch and Viking Press.

Pant, Harsh V. 2017. "Unless China changes tack, India won't be the only country opposing One Belt, One Road," Quartz Media. 23 Jun. https://qz.com/1012929/unless-china-changes-tack-india-wont-be-the-only-countryopposing-one-belt-one-road/?utm_source=YPL\&yptr=yahoo

Paul, Ronald E. 2006. “The End of Dollar Hegemony," Resilience.org. 20 Feb. http://www.resilience.org/stories/2006-02-20/end-dollar-hegemony/

Perez, Louis. 1989. Lords of the Mountain: Banditry and Peasant Protest in Cuba, 1878-1918. Pittsburgh: University of Pittsburgh Press.

Pollmann, Mina. 2017. "Even Japan Is Now Considering Joining China's One Belt, One Road," Russian Insider. 15 Jun. http://russia-insider.com/en/politics/even-japan-now-considering-joining-chinas-one-belt-oneroad/ri20114?ct=t\%28Russia_Insider_Daily_Headlines11_21_2014\%29\&mc_cid=7c8b7ce690\&mc_eid=f34613da $8 \mathrm{c}$

Rachman, Gideon. 2017. Easternization: Asia's Rise and America's Decline From Obama to Trump and Beyond. New York: Other Press.

Raleigh, Helen. 2017. “China's 'Project Of Century’ Aims To Unseat U.S. As World's Top Power,” The Federalist. 12 Jun. http://thefederalist.com/2017/06/12/chinas-project-century-aims-unseat-u-s-worlds-dominant-power/

Roberts, Priscilla. 1994. "The first world war and the emergence of American Atlanticism, 1914-1920," Diplomacy and Statecraft, Vol. 5, No. 3, 569-619. Nov. http://www.tandfonline.com/doi/ref/10.1080/09592299408405947 
Roberts, Priscilla. 1997. “The Anglo-American Theme: American Visions of an Atlantic Alliance, 1914-1933,” Diplomatic History, Vol. 21, No. 3, 333-364. Jul. https://www.researchgate.net/publication/229788660_The_AngloAmerican_Theme_American_Visions_of_an_Atlantic_Alliance_1914-1933_Prizewinning_article_1997_Arthur_Miller_Prize_for_the_best_British_article_in_American_studies_British_Association_o f_Ameri

Roberts, Priscilla. 2005. "Paul D. Cravath, The First World War, and the Anglophile Internationalist Tradition," Australian Journal of Politics and History, Vol. 51, No. 2, 194-215. Jun. file://C:/Users/Windy/AppData/Local/Temp/cravath\%20article-1.pdf

Roberts, Priscilla, ed. 2006. Behind the Bamboo Curtain: China, Vietnam and the World Beyond Asia. Stanford: Stanford University Press.

file:///C:/Users/Windy/AppData/Local/Temp/Behind\%20the\%20Bamboo\%20Curtain.pdf

Ross, Eleanor. 2017. "South China Sea: Chinese Military Planes Raise New Concerns of Conflict in Asia," Newsweek. 23 Jun. http://www.newsweek.com/south-china-sea-chinese-military-planes-raise-new-concerns-conflict-asia628479

Rothman, Noah. 2017. "The End of Atlanticism," Commentary. 17 Jan. https://www.commentarymagazine.com/foreign-policy/europe/the-end-of-atlanticism-nato/

Saunders, Phillip C. 2010. “Will China's Dream Turn Into America's Nightmare?” China Brief, Vol. 10, No. 7. Washington: Jamestown Foundation.

http://www.jamestown.org/single/?no_cache=1\&tx_ttnews\%5Btt_news\%5D=36217\&tx_ttnews\%5BbackPid\%5D $=7 \& \mathrm{cHash}=19 \mathrm{fc} 1 \mathrm{~b} 4 \mathrm{da} 3$.

Shim, Elizabeth. 2017. “China drills, finds 'burning ice' in South China Sea," United Press International (UPI). 12 Jun. http://www.upi.com/Top_News/World-News/2017/06/12/China-drills-finds-burning-ice-in-South-ChinaSea/5861497281536/

Spillover Report. 2014. International Monetary Fund (IMF) Multilateral Policy Issues Report. Washington: International Monetary Fund. 29 Jul. http://www.imf.org/external/np/pp/eng/2014/062514.pdf

Taft, William Howard. 1912. Fourth Annual Message to the Congress. Washington: National Archives. 03 Dec. https://millercenter.org/the-presidency/presidential-speeches/december-3-1912-fourth-annual-message

Tartar, Andre, and Wei Lu. 2017. “China's Rags-to-Riches Transformation Isn't Over Yet,” Bloomberg. 25 Jun. https://www.bloomberg.com/amp/news/articles/2017-06-25/there-s-no-end-in-sight-for-china-s-rise-up-thegdp-rankings

“The Hidden Motives of the Chinese Silk Road," Yale Global. 24 June 2017. http://oilprice.com/Energy/EnergyGeneral/The-Hidden-Motives-Of-The-Chinese-Silk-Road.html

The United States and China in Power Transition. Cleveland, OH: 2017, Progressive Management Publications. https://www.amazon.com/United-States-China-Power-

Transition/dp/1521319685?SubscriptionId=AKIAJTPUO22B732H2OVA\&tag=ndkglobal20\&linkCode $=x m 2 \&$ camp $=2025 \&$ creative $=165953 \&$ creativeASIN=1521319685\#reader_1521319685

Timoneda, Joan Carreras. 2008. "Dollar Diplomacy: Fallacies and Consequences of Foreign Investment in the Cuban Economy, 1909-1924," Association for the Study of the Cuban Economy (ASCE), 275-283. 30 Nov. http://www.ascecuba.org/c/wp-content/uploads/2014/09/v18-carrerastimoneda.pdf

Trani, Edward P. 2002. “Dollar Diplomacy,” Encyclopedia.com. http://www.encyclopedia.com/history/unitedstates-and-canada/us-history/dollar-diplomacy

Varandani, Suman. 2017. “North Korea Ready To Attack US? Kim Jong Un's Regime Won't Negotiate Over Nuclear Program, Report Says," International Business Times. 25 Jun. http://www.ibtimes.com/north-korea-ready-attackus-kim-jong-uns-regime-wont-negotiate-over-nuclear-program-2557077

"Voice of America director cut short Guo Wengui live interview," BBG Watch. 01 May 2017. http://bbgwatch.com/bbgwatch/voice-of-america-director-cut-short-guo-wengui-live-interview/

Wang, Brian. 2017. "China is moderating economic weaknesses and may become reliable global engine in 5-15 years," NextBigFuture. 25 Jun. https://www.nextbigfuture.com/2017/06/china-is-moderating-economicweaknesses-and-may-become-reliable-global-engine-in-5-15-years.html 
Wang, Xiangwei. 2017. “Opinion: China's robber barons take collusion to a whole new level,” South China Morning Post. 14 May. http://www.scmp.com/week-asia/opinion/article/2098421/billionaire-wus-detention-signalschinas-clean-financial-sector

Wither, James. 2006. "An Endangered Partnership: The Anglo-American Defence Relationship in the Early Twenty-first Century,” European Security, Vol. 15, No. 1, 47-65. 17 Jul. http://www.tandfonline.com/doi/abs/10.1080/09662830600776694

Yamaguchi, Mari. 2017. "Japan seeks to expand arms deals with Southeast Asia," ABC News from AP. 12 Jun. http://abcnews.go.com/International/wireStory/japan-seeks-expand-arms-deals-southeast-asia-47979260

Yan, Sophia. 2014. “Alibaba has a major counterfeit problem,” Cable News Network (CNN). 12 Sep. http://money.cnn.com/2014/09/11/technology/alibaba-counterfeit-ipo/index.html

Zakaria, Fareed. 2009. The Post-American World. New York: W.W. Norton. 